\title{
UPAYA MENINGKATKAN PEMAHAMAN KONSEP SISWA SEKOLAH DASAR MELALUI PENERAPAN MODEL KANCING GEMERINCING
}

\author{
Solehudin \\ SDN Cingambul III Majalengka, Indonesia \\ solehudin08@gmail.com
}

\begin{abstract}
This research is motivated by the lack of understanding of students' concepts in social studies learning about the appearance of nature and socio-cultural diversity in class IV SDN Cingambul III. One solution that is considered appropriate in improving understanding of concepts is the jingle button model. On that basis, this study aims to apply the jangle button model to improve understanding of concepts. The method used in this research is classroom action research (CAR) which is carried out in two cycles. The subjects in this study were students in grade IV SDN Cingambul III. The results showed the results of the students' understanding of the concept tests in each cycle increased. Thus, it can be concluded that through the clanging button model can improve students' understanding of concepts in social studies learning the appearance of nature and socio-cultural diversity in Cingambul III Elementary School, Cingambul District, Majalengka Regency.
\end{abstract}

Keywords: jingle button model, concept understanding, social studies learning.

\begin{abstract}
ABSTRAK
Penelitian ini dilatarbelakangi oleh rendahnya pemahaman konsep siswa pada pembelajaran IPS materi kenampakan alam dan keragaman sosial budaya di kelas IV SDN Cingambul III. Salah satu solusi yang dianggap tepat dalam meningkatkan pemahaman konsep adalah Model Kancing Gemerincing. Atas dasar itu, penelitian ini bertujuan menerapkan model Kancing Gemerincing untuk meningkatkan pemahaman konsep. Metode yang digunakan dalam penelitian ini adalah penelitian tindakan kelas (PTK) yang dilaksanakan dalam dua siklus. Sebjek dalam penelitian ini yaitu siswa kelas IV SDN Cingambul III. Hasil penelitian menunjukkan hasil tes pemahaman konsep siswa di setiap siklus mengalami peningkatan. Dengan demikian, dapat disimpulkan bahwa melalui model kancing gemerincing dapat meningkatkan pemahaman konsep siswa pada pembelajaran IPS materi kenampakan alam dan ragam sosial budaya di SDN Cingambul III Kecamatan Cingambul Kabupaten Majalengka.
\end{abstract}

Kata Kunci: model kancing gemerincing, pemahaman konsep, pembelajaran IPS.

Submitted Feb 28, 2020 | Revised Mar 18, 2020 | Accepted Mar 20, 2020

\section{Pendahuluan}

Pendidikan berfungsi mengembangkan kemampuan dan membentuk watak serta peradaban bangsa yang bermartabat dalam rangka mencerdaskan kehidupan bangsa. Sebagaimana tercantum dalam UU Sisdiknas No. 20 tahun 2003 pasal 3, yang menyatakan bahwa Pendidikan bertujuan untuk mengembangkan potensi peserta didik agar menjadi manusia yang beriman dan bertakwa kepada Tuhan Yang Maha Esa, berakhlak mulia, sehat, berilmu, cakap, kreatif mandiri, dan menjadi warga yang demokratis serta bertanggung jawab.

Hal tersebut menjelaskan bahwa begitu luhurnya cita-cita bangsa Indonesia dalam bidang pendidikan. Tentu dalam mewujudkan atau membangun pribadi yang berkualitas, perlu 
upaya yang maksimal dalam merealisasikan tujuan pendidikan tersebut baik guru, pemerintah, serta masyarakat. Peran guru dalam melaksanakan pembelajaran di sekolah sebagai suatu upaya mencerdaskan siswa memang menjadi sesuatu hal yang penting. Guru sebagai ujung tombak pendidikan harus berupaya secara maksimal dalam melaksanakan kewajibannya yaitu mengajar dan mendidik agar terciptanya siswa yang benar-benar diharapkan.

Ilmu pengetahuan sosial (IPS) merupakan salah satu mata pelajaran yang diberikan pada jenjang pendidikan dasar dan menengah atau nama program studi di perguruan tinggi yang identik dengan istilah "social studies". Ilmu pengetahuan sosial (IPS) adalah bidang pengetahuan dan penelaahan gejala dan masalah sosial di masyarakat yang ditinjau dari berbagai aspek kehidupan sosial, dalam usaha mencari jalan keluar dari masalah masalah tersebut (Lestari, Ansori, \& Nahdi, 2019). Menurut Somantri (Sapriya, 2009: 7), menyatakan Ciri khas IPS sebagai mata pelajaran pada jenjang pendidikan dasar dan menengah adalah sifat terpadu (integrated) dari sejumlah mata pelajaran dengan tujuan agar mata pelajaran ini lebih bermakna bagi peserta didik sehingga pengorganisasian materi/bahan pelajaran disesuaikan dengan lingkungan, karakteristik, dan kebutuhan peserta didik. Mata pelajaran IPS dirancang untuk mengembangkan pengetahuan, pemahaman, dan kemampuan analisis peserta didik terhadap keadaan sosial masyarakat dalam memasuki kehidupan masyarakat yang dinamis. Hal tersebut sesuai dengan tujuan IPS SD/MI yang tertuang dalam KTSP yaitu:

1. Mengenal konsep-konsep yang berkaitan dengan kehidupan masyarakat, dan lingkungannya.

2. Memiliki kemampuan dasar untuk berfikir kritis, rasa ingin tahu, inquiri, memecahkan masalah, dan keterampilan dalam kehidupan sosial.

3. Memiliki komitmen dan kesadaran terhadap nilai-nilai sosial dan kemanusiaan.

4. Memiliki kemampuan berkomunikasi, bekerjasama, dan berkompetensi dalam masyarakat yang majemuk, ditingkat lokal, nasional dan global.

Memperhatikan tujuan dan pentingnya pendidikan IPS bagi siswa sekolah dasar, dibutuhkan suatu pola pembelajaran yang mampu menjembatani tercapainya tujuan tersebut. Guru diharapkan memiliki kemampuan serta keterampilan dalam memilih ataupun menggunakan berbagai model, metode, dan strategi pembelajaran (Ulfa \& Saifudin, 2018) agar pembelajaran IPS di Sekolah Dasar benar-benar mampu mengkondisikan upaya pembekalan kemampuan dan keterampilan dasar bagi siswa untuk menjadi manusia dan warga negara yang baik. Hal ini dapat diwujudkan melalui kegiatan pembelajaran yang efektif, dimana guru mampu merangsang siswa-siswanya untuk aktif dalam proses pembelajaran.

Kegiatan pembelajaran yang dilakukan harus menarik dan lebih menekankan pada proses dari pada hasil, yaitu proses bagaimana siswa memperoleh pengetahuannya. Siswa tidak menerima pengetahuan dari guru secara pasif, melainkan siswa yang berperan secara aktif dalam memperoleh dan membangun pengetahuan-pengetahuan baru. Keberhasilan guru dalam proses pembelajaran ditentukan oleh siswa yang dapat menguasai materi pembelajaran dengan baik sehingga tingkat pemahaman konsep materi siswa akan meningkat yang mana berdampak pada hasil belajar siswa yang di harapkan dalam pembelajaran dapat tercapai.

Dari tujuan pembelajaran IPS di atas dapat disimpulkan bahwa Pemahaman konsep sangat penting, karena penguasaan konsep akan memudahkan siswa dalam pembelajaran IPS. Pemahaman konsep merupakan suatu kemampuan yang dimiliki oleh individu sehingga dapat memberikan suatu pemahaman terhadap suatu kajian. Pemahaman konsep adalah kemampuan 
peserta didik yang berupa penguasaan sejumlah mata pelajaran, tetapi mampu mengungkapkan kembali dalam bentuk lain yang mudah dimengerti, memberikan interpretasi data dan mampu mengaplikasikan konsep yang sesuai dengan stuktur kognitif yang dimilikinya.

Dengan demikian dapat penulis simpulkan bahwa pemahaman konsep adalah proses menyerap untuk memahami ide atau pengertian-pengertian yang diabstrakan dari peristiwa yang kongkrit. Memaknai suatu materi atau informasi yang dipelajari lebih dari sekedar mengingat, tetapi mampu menerapkan menganalisis dan mengevaluasi.

Namun pada kenyatanya, pelaksanaan proses pembelajaran ilmu pengetahuan sosial (IPS) yang diterapkan di SDN Cingambul III masih lemah.Berdasarkan hasil observasi yang di lakukan penulis pada tanggal 26 januari 2016 dan penulis bertanya pada guru kelas 4 di SDN Cingambul III tentang pembelajaran IPS di SDN Cingambul III Kecamatan Cingambul Kabupaten Majalengka. Penulis menemukan permasalahan-permasalahan yang ada di kelas tersebut. Diketahui bahwa kriteria ketuntasan minimal (KKM) di kelas IV SDN Cingambul III adalah 73, Masih banyak siswa yang nilainya masih di bawah KKM yang di tentukan oleh sekolah.

Proses pembelajaran di sekolah cenderung masih menggunakan metode ceramah, menjadikan guru sebagai sumber utama pembelajaran dan umumnya kurang melibatkan aktivitas siswa secara optimal dalam pembelajaran. Kecenderungan pembelajaran tersebut dapat menimbulkan siswa kurang aktif dan menyebabkan isi pelajaran IPS sebagai hafalan. Proses pembelajaran yang terjadi selama ini kurang mampu mengembangkan kemampuan berfikir siswa. Pelaksanaan proses pembelajaran hanya diarahkan agar siswa mampu untuk menghapal informasi yang disampaikan oleh guru.

Otak siswa dipaksa untuk mengingat tanpa dituntut untuk mencerna dan memahami makna yang terkandung didalamnya dan tidak dihubungkan dengan kehidupan sehari-hari. Padahal teori belajar menurut Djamarah (2011: 17) menyatakan bahwa "penguasaan bahan yang bersifat hapalan biasanya jauh dari pengertian. Lebih lanjut lagi, Djamarah (2011: 29) berpendapat "jika menghapal tanpa pengertian menjadi kabur".

Untuk menciptakan pembelajaran IPS yang bermakna, maka guru harus mampu mendesain model pembelajaran yang memungkinkan siswa dapat berpartisipasi, aktif, kreatif pada materi yang diajarkan. Dengan cara demikian, diharapkan siswa dapat memahami materi yang diberikan dan mencapai pembelajaran yang bermakna. Joyce (Trianto, 2009: 22) menyatakan bahwa "setiap model pembelajaran mengarahkan kita kedalam mendesain pembelajaran untuk membantu peserta didik sedemikian rupa sehingga tujuan pembelajaran tercapai". Model pembelajaran yang digunakan dalam kegiatan pembelajaran tidak hanya untuk mencapai tujuan tetapi disesuaikan pula dengan bahan atau materi pembelajaran serta karakteristik dan kebutuhan siswa.

Model pembelajaran kancing gemerincing (talking chips) merupakan salah satu model yang dianggap dapat menjadikan minat siswa terhadap IPS meningkat. Hasil penelitian yang dilakukan Asteriyana (2013), Endang \& Sore (2013), Erika, Sumardi \& Rosarina (2018), dan Fiona, Rapani, \& Siswantoro (2019) membuktikan bahwa model ini berhasil dalam meningkatkan pencapaian siswa dalam hasil belajar.

Menurut Miftahul (2011) Model pembelajaran kancing gemerincing merupakan suatu model yang efisien untuk menciptakan diskusi para siswa mengenai konsep ilmu pengetahuan sosial. Model kancing gemerincing digunakan dalam semua mata pelajaran dan untuk semua 
tingkatan usia anak didik. Dalam kegiatan kancing gemerincing, masing masing anggota kelompok mendapatkan kesempatan untuk memberikan kontribusi mereka dan mendengarkan pandangan dan pemikiran anggota lain. Model kancing gemerincing ini untuk mengatasi hambatan pemerataan kesempatan yang sering mewarnai kerja kelompok, dalam kerja kelompok sering ada anggota yang terlalu dominan dan banyak bicara. Sebaliknya, juga ada anggota kelompok yang pasif dan pasrah saja pada rekannya yang lebih dominan.

Model kancing gemerincing memastikan bahwa setiap siswa mendapat kesempatan untuk berperan serta. Pembelajaran dengan menggunakan model kancing gemerincing sesuai dengan karakter anak SD yakni senang bermain, bergerak bekerja dalam kelompok. Pembelajaran ini memungkinkan siswa untuk bergerak dan bekerja atau belajar dalam kelompok, mengandung unsur permainan.

\section{Metode Penelitian}

Metode penelitian yang dilakukan penulis adalah Penelitian Tindakan Kelas (PTK) yang mengacu kepada tindakan guru ketika melaksanakan pembelajaran sebagai upaya untuk memperbaiki kegiatan pembelajaran yang telah dilaksanakan. Hal ini sesuai dengan pernyataan Suharjono (Arikunto, 2006:58) yang mengemukakan bahwa "penelitian tindakan kelas adalah penelitian tindakan yang dilakukan di kelas dengan tujuan memperbaiki/meningkatkan mutu praktik belajar".

Desain PTK yang digunakan yaitu model siklus menurut Kemis dan Mc.Taggart (Suyanto, 1997) yaitu terdiri dari empat komponen yaitu :

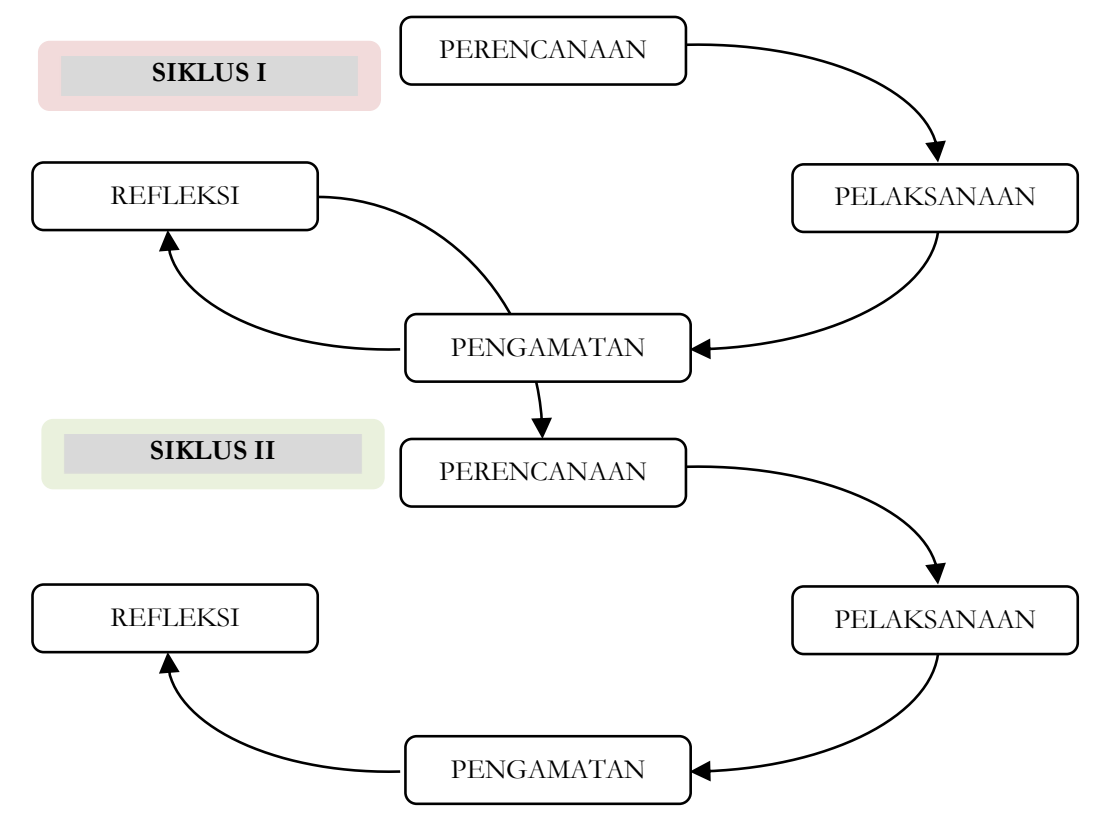

Gambar 1 PTK Model Spiral dari Kemmis S. dan Mc. Taggart, R Trianto (2011)

PTK ini dilaksanakan berdasarkan tahapan-tahapan sebagai berikut: "(1) merencanakan tindakan, (2) melaksanakan tindakan, (3) melaksanakan observasi, (4) melakukan refleksi." (Kasbolah, 1999). Keempat komponen yang berupa untaian tersebut dipandang sebagai satu 
siklus. Oleh karena itu, pengertian siklus adalah suatu putaran kegiatan yang terdiri dari perencanaan, tindakan, pengamatan dan refleksi. Prosedur yang digunakan dalam penelitian ini digunakan prosedur tindakan kelas ( Classroom Action Research) yang dikembangkan oleh Kemmis dan Mc Taggart dengan sistem spiral refleksi. Ada beberapa alasan mengapa dalam penelitian menggunakan Penelitian Tindakan Kelas ( PTK), diantaranya (1) Penelitian tindakan kelas menawarkan cara baru dalam memperbaiki dan meningkatkan kemampuan/profesionalisme dalam kegiatan pembelajaran di kelas; (2) Penelitian tindakan kelas tidak membuat guru meninggalkan tugasnya, artinya guru tetap melakukan kegiatan pembelajaran seperti biasa, namun pada saat bersamaan secara integrasi guru melaksanakan penelitian; (3) Penelitian tindakan kelas dapat sebagai pelatihan dalam jabatan, sehingga membekali guru yang bersangkutan dengan keterampilan dan teknik mengajar yang baru.

Sesuai dengan metode Penelitian Tindakan Kelas ( PTK), prosedur yang akan ditempuh terdiri dari 2 siklus, tetapi jika hasil refleksi menghendaki tindakan lanjutan maka akan dilaksanakan siklus selanjutnya, setiap siklus terdiri dari tahapan yang saling terkait dan berkesinambungan, yaitu tahap perencanaan atau persiapan, pelaksaan, pengamatan atau observasi dan refleksi.

\section{Hasil dan Pembahasan}

Penerapan model kancing gemerincing pada pembelajaran IPS di kelas IV SDN Cingambul III I, merupakan sesuatu yang baru bagi siswa, karena biasanya para guru disana pada saat melaksanakan pembelajaran hanya menggunakan metode ceramah dan penugasan. Padahal guru itu dituntut untuk dapat mengembangkan pembelajaran menjadi lebih aktif dan kreatif. Misalnya dalam pembelajaran guru menggunakan model atau metode pembelajaran yang dapat membangkitkan minat belajar siswa dan menjadikan pembelajaran dikelas aktif.

Untuk mencapai hasil belajar yang optimal siswa harus belajar dengan aktif. Hisyam Zaini, dkk (2009:14) "Belajar aktif itu sangat diperlukan oleh peserta didik untuk mendapatkan hasil belajar yang maksimum. Ketika peserta didik pasif, atau hanya menerima dari pengajar, ada kecenderungan untuk cepat melupakan apa yang telah diberikan". Banyak hal yang dapat gunakan dalam mengembangakan pembelajaran salah satunya dengan model pembelajaran aktif agar siswa dapat belajar aktif dalam pembelajaran.

Dengan penerapan model kancing gemerincing selama 4 tindakan pada 2 siklus telah menunjukan peningkatan terhadap pemahaman konsep siswa kelas IV SDN Cingambul III pada mata pelajaran IPS. Untuk meningkatkan pemahaman konsep siswa model pembelajaran kancing gemerincing sangat bagus untuk digunakan, karna model kancing gemerincing bisa digunakan dalam semua pelajaran dan untuk tingkatan usia anak didik. Pembelajaran menggunakan kancing gemerincing berpusat pada siswa Jadi pembelajaran yang dilaksanakan tidak berpusat pada guru tetapi lebih berpusat pada siswa karena disini siswa yang mencari informasi sendiri guru hanya fasilitator dan moderator yang mengarahkan jalannya pembelajaran.

Dalam penerapan model pembelajaran kancing gemerincing pada tindakan I ada sedikit kendala yaitu beberapa orang siswa masih kurang paham bagaimana cara menggunakan kancing yang diberikan peneliti, jadi mereka hanya bengong dan gak ikut aktif dalam kelompok. Tetapi pada tindakan II samapai dengan tindakan IV mereka mulai memahami bagaimana mencari menggunakan kancing tersebut dan mengikuti langkah-langkah belajar 
menggunakan model kancing gemerincing. Siswa sangat semangat ketika peneliti menugaskan untuk menggunakan kancing itu dan diberi bahan ajar agar mereka bisa bertanya. Selain itu ada kendala yang dialami peneliti pada tindakan I yaitu peneliti kurang bisa mengkondisikan kelas karena masih terlihat ada siswa yang mengobrol pada saat peneliti menjelaskan materi. Atas saran dari guru kelas untuk tindakan selanjutnya peneliti mulai bisa mengkondisikan kelas dengan baik.

Dalam pelaksanaan pembelajaran IPS di kelas IV SDN Cingambul III I masih ditemukan beberapa masalah, sehingga berpengaruh terhadap pemahaman konsep siswa yang rendah. Hal tersebut dapat dilihat dari hasil belajar siswa yang belum tuntas mecapai nilai KKM. pada pra siklus siswa yang mencapai KKM hanya 7 orang atau sekitar $28 \%$ dari 25 orang siswa. Dari siswa yang tuntas mencapai KKM meunjukan bahwa pemahan konsep siswa pada mata pelajaran IPS masih rendah khususnya pada materi tentang Kenampakan alam dan sosial budaya.

Setelah melakukan diskusi dengan guru kelas dan melihat pembelajaran yang dilakukan guru kelas IV. Faktor apa yang menyebabkan pemahaman konsep siswa terhadap mata pelajaran IPS sangat rendah. Peneliti melihat faktor yang menyebabkan pemahaman konsep siswa sangat rendah, yaitu guru hanya menggunakan metode ceramah dan penugasan pada saat menyampaikan materi pelajaran. Tidak adanya variasi dalam pembelajaran menyebabkan siswa kurang tetarik pada pembelajaran dan pemahaman konsep siswa menjadi rendah.

Untuk meningkatkan pemahaman konsep siswa pada mata pelajaran IPS, peneliti tertarik untuk menerapkan model pembelajaran kancing gemerincing. Penerapan model pembelajaran kancing gemerincing tersebut bertujuan untuk perbaikan pembelajaran. Model pembelajaran kancing gemerincing adalah model pembelajaran yang mengembangkan hubungan timbal balik antara anggota kelompok yang di dasari kepentingan yang sama. Menurut peneliti model tersebut sangat cocok digunakan untuk upaya meningkatkan pemahaman konsep siswa, Penerapan model pembelajarn kancing gemerincing ini diharapkan dapat meningkatkan pemahaman konsep siswa di kelas IV SDN Cingambul III I pada mata pelajaran IPS pada materi keragaman alam dan sosial budaya.

Model pembelajaran kancing gemerincing ini dapat meningkatkan pemahaman konsep siswa pada mata pelajaran IPS, pernyataan tersebut dapat dilihat pada tabel dan diagram keberhasilan siklus PTK berikut ini:

Tabel 1

Rekapitulasi Ketuntasan Belajar Siswa

\begin{tabular}{llllll}
\hline \multirow{2}{*}{ No. } & \multicolumn{1}{c}{ Siklus } & \multicolumn{2}{c}{ Ketuntasan } & \multicolumn{2}{c}{ Persentase (\%) } \\
& & Tuntas & Belum Tuntas & Tuntas & Belum Tuntas \\
\hline 1. & Pra Siklus & 7 & 18 & $28 \%$ & $72 \%$ \\
2. & Siklus I Tindakan 1 & 10 & 15 & $40 \%$ & $60 \%$ \\
3. & Siklus I Tindakan 2 & 14 & 11 & $56 \%$ & $44 \%$ \\
4. & Siklus II Tindakan 1 & 18 & 7 & $72 \%$ & $28 \%$ \\
5. & Siklus II Tindakan 2 & 24 & 1 & $96 \%$ & $1 \%$ \\
\hline
\end{tabular}

Pada tabel di atas dapat dilihat bahwa pada setiap tindakan hasil evaluasi siswa selalu mengalami peningkatan. siswa yang tuntas mencapai KKM mata pelajaran IPS siklus I tindakan 1 40\% dan tindakan II 56\% sedangkan pada siklus II tindakan $172 \%$ dan pada tindakan II 96\%. Hal tersebut berarti bahwa penerapan model pembelajaran kancing 
gemerincing cukup efektif diterapkan dalam upaya meningkatkan pemahamana konsep siswa terhadap mata pelajaran IPS. untuk melihat peningkatan pemahaman konsep siswa terhadap mata pelajaran IPS dengan menggunakan model kancing gemerincing peneliti gambarkan keberhasilan siklus PTK di atas dalam diagram batang berikut ini:

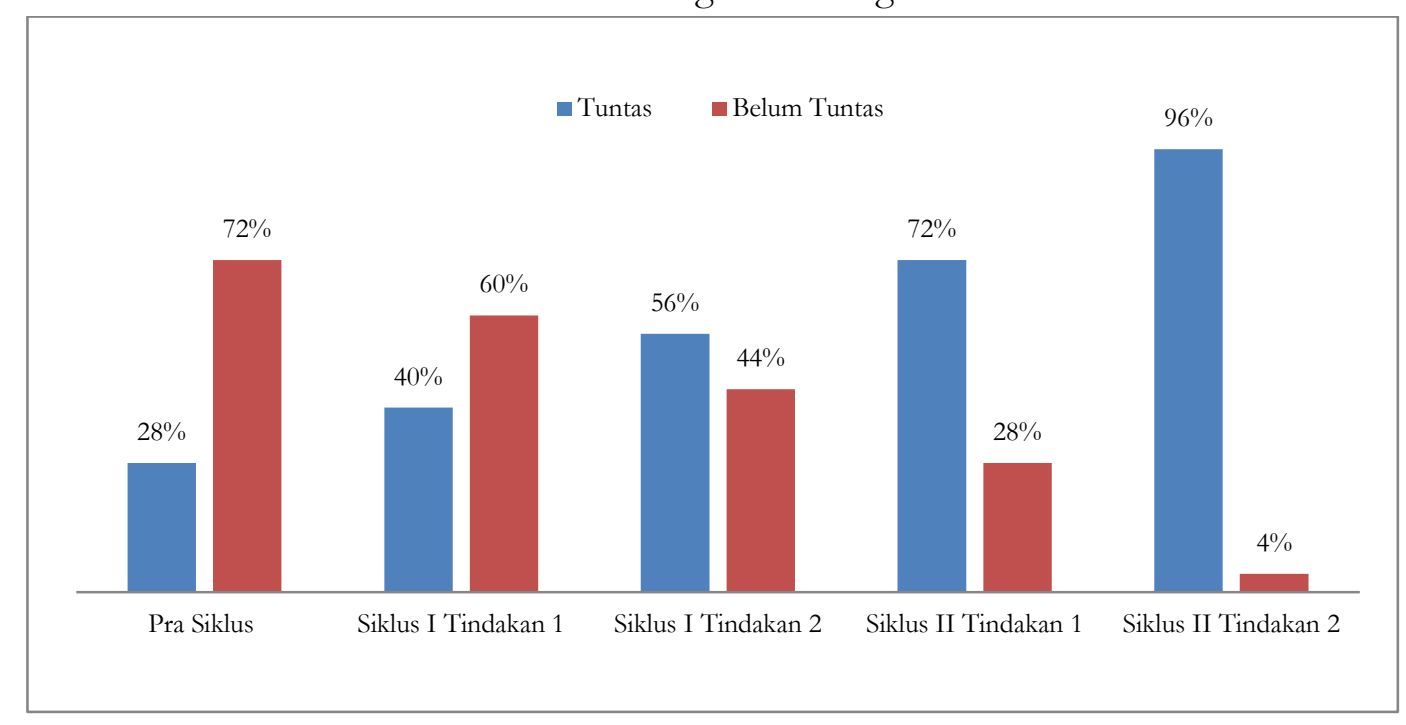

Gambar 2

Diagram Rekapitulasi Ketuntasan Belajar Siswa

Berdasarkan data di atas dapat disimpulkan bahwa setelah diterapkannya model pembelajaran kancing gemerincingdi kelas IV SDN Cingambul III, terjadi peningkatan pemahaman konsep siswa pada mata pelajaran IPS materi tentang koperasi. Peningkatan dari pra siklus, siklus I sampai dengan siklus II sebanyak 68\%. Siswa yang tuntas mencapai KKM pada siklus I tindakan 1 sebanyak 10 orang (40\%) dan pada tindakan II sebanyak 14 orang (56\%). Pada siklus II tindakan 1 siswa yang tuntas mencapai KKM yaitu sebanyak 18 orang $(72 \%)$ dan pada tindakan II sebanyak 24 siswa (96\%). Sedangkan siswa yang belum mencapai nilai KKM pada siklus I tindakan 1 yaitu 15 orang $(60 \%)$ dan pada tindakan II yaitu 11 orang (44\%). Dan pada siklus II tindakan 1 yaitu 7 orang (28\%) dan pada tindakan 2 yaitu 1 orang $(4 \%)$.

Dapat disimpulkan bahwa indikator keberhasilan siswa yang tuntas dari nilai KKM telah tercapai atau terpenuhi, bahkan melebihi dari indikator keberhasilan siswa yaitu 24 orang atau 96\% dari jumlah siswa 25 orang. Maka peneliti memutuskan untuk menghentikan Penelitian Tindakan Kelas (PTK) ini sampai pada siklus II.

Jadi model pembelajaran kancing gemerincing dapat meningkatkan pemahaman konsep siswa kelas IV SDN Cingambul III terhadap mata pelajaran IPS. Hal tersebut dapat dilihat dari hasil Penelitian Tindakan Kelas (PTK) yang telah dilakukan sebanyak 2 siklus, setiap siklus terdiri dari dua tindakan. Pada setiap tindakan siswa yang tuntas mencapai nilai KKM mata pelajaran IPS yaitu 73, selalu mengalami peningkatan hal tersebut berarti pemahaman konsep siswa pun meningkat. Dan indikator keberhasilan pemahaman konsep siswa yaitu 25 orang siswa yang tuntas mencapai KKM atau sekitar 80\% dari 25 orang siswa telah tercapai, bahkan hasil evaluasi siswa melebihi dari indikator. Peneliti menyimpulkan bahwa penerapan model pembelajaran kancing gemerincing cukup efektif dalam meningkatkan pemahaman konsep siswa pada mata pelajaran IPS. 
Penerapan model pembelajaran kancing gemerincing juga efektif dalam meningkatkan kemampuan menulis siswa pada mata pelajaran Bahasa Indonesia, hal tersebut berdasarkan pada Penelitian Tindakan Kelas yang dilakukan oleh fatoni (2002) yang berjudul "Penerapan Model Pembelajaran Kooperatif Tipe Kancing Gemerincing untuk Meningkatkan Kemampuan Menulis dalam Melengkapi Cerita Rumpang di Kelas IV Sekolah Dasar Negeri Cingambul III Kecamatan Cingambul Kabupaten Majalengka" Hasil penelitian menunjukan peningkatan kemampuan menulis pada pembelajran Bahasa Indonesia. Hal ini terbukti dari keampuan menulis siswa pada kondisi awal 28,56\% mengalami peningkatan pada siklus I sebesar 49,07\% dan 64,28\%, dan pada siklus II sebesar 81,24\% dan 87,49\%. Hasil belajar siswa pada kondisi awal 28,57\% mengalami peningkatan pada siklus I sebesar 37,03\% dan $57,14 \%$, pada siklus II sebesar 87,5\% dan 95,83\% . dengan demikian dapat disimpulkan bahwa penerapan model kancing gemerincing dapat meningkatkan kemampuan menulis pada pembelajaran Bahasa Indonesia siswa kelas IV Sekolah Dasar Negeri Cingambul III Kecamatan Cingambul Kabupaten Majalengka.

\section{Kesimpulan}

Penerapan model pembelajaran kancing gemerincing dapat meningkatkan pemahaman konsep siswa pada mata pelajaran IPS di kelas IV SDN Cingambul III. Hal tersebut pada berdasarkan hasil penelitian pada setiap siklus yang mengalami peningkatan. Pemahaman konsep siswa kelas IV SDN Cingambul III pada mata pelajaran IPS meningkat, hal tersebut dapat dilihat dari data hasil evalusi siswa dalam Penelitian Tindakan Kelas (PTK) dengan menggunakan model pembelajaran kancing gemerincing. Pembelajaran IPS dengan menggunakan model pembelajaran kancing gemerincing dapat meningkatkan pemahaman konsep siswa pada mata pelajaran IPS di kelas IV SDN Cingambul III.

\section{Daftar Pustaka}

Arikunto, S. (2006). Penelitian Tindakan Kelas. Jakarta : PT Bumi Aksara

Asteriyana. (2013). Peningkatan Hasil Belajar Ips Dengan Menggunakan Model Pembelajaran Kooperatif Tipe Kancing Gemerincing di SD. Pembelajaran Inovasi, Jurnal Ilmiah Pendidikan Dasar, 1(1).

Djamarah, S. (2010). Guru Dan Anak Didik Dalam Interaksi Eduktif. Jakarta : Ptrineka cipta.

Endang, \& Sore, A.D., (2016). Peningkatan Hasil Belajar Siswa Melalui Model Kancing Gemerincing Di Kelas VIII Sekolah Menengah Pertama Negeri 7 Belimbing. Jurkami: Jurnal Pendidikan Ekonomi, 1(1), 44-53.

Erika, D., Sumardi, \& Rosarina. (2018). Pengaruh Model Cooperative Learning Tipe Kancing Gemerincing Terhadap Hasil Belajar Siswa Pembelajaran IPS di SD. Pedadidaktika: Jurnal Ilmiah Pendidikan Guru Sekolah Dasar, 5(1), 140-152.

Fiona, F., Rapani, \& Siswantoro. (2019). Pengaruh Model Kooperatif Tipe Kancing Gemerincing terhadap Hasil Belajar. Jurnal Pedagogi, 1(3).

Kasbolah (1998). Penelitian Tindakan Kelas. Malang; Depdikbud.

Miftahul, H. (2011). Coopratif Learning. Yogyakarta : pustaka pelajar 
Lestari, F. Y. P., Ansori, Y. Z., \& Nahdi, D. S. (2019). Model Inkuiri Terbimbing Dalam Meningkatkan Keterampilan Berpikir Kritis IPS Siswa SD. Prosiding Seminar Nasional Pendidikan FKIP Universitas Majalengka, 509-516. Retrieved from http://prosiding.unma.ac.id/index.php/semnasfkip/article/view/73

Sapriya. (2009). Pendidikan IPS. Bandung: Rosda Karya.

Suyanto.(1997). Pedoman pelaksaaa penelitian kelas. Jakarta: Dirjen Dikti.

Trianto (2009). Mendesain Model Pembelajaran Inovatif Progresif. Surabaya: Kencana.

Trianto. (2011). Model Pembelajaran Terpadu Konsep,Strategi Dan Implementasinya. Dalam Kurikulum Tingkat Satuan Pendidikan (KTSP). Jakarta : Bumi Aksara.

Ulfa, M \& Saifuddin. (2018). Terampil Memilih Dan Menggunakan Metode Pembelajaran. SUHUF, 30( 1), 35-56. 